\title{
GAMBARAN EUTIROID PADA PASIEN STRUMA MULTINODUSA NON-TOKSIK DI BAGIAN BEDAH RSUP PROF. DR. R. D. KANDOU MANADO PERIODE JULI 2012 - JULI 2014
}

\author{
${ }^{1}$ Syaugi M. Assagaf \\ ${ }^{2}$ Nico Lumintang \\ ${ }^{2}$ Harsali Lampus \\ ${ }^{1}$ Kandidat Skripsi Fakultas Kedokteran Universitas Sam Ratulangi Manado \\ ${ }^{2}$ Bagian Bedah BLU RSUP Prof. Dr. R. D. Kandou Manado \\ Email: syaugiassagaf@gmail.com
}

\begin{abstract}
Goitre is a thyroid gland enlargement due to the increase of thyroid tissue. Goitre can be classified from several aspects: physiological (euthyroidsm, hypothyroidsm, and hyperthyroidism), morphological (diffuse and nodular goitre), and clinical (toxic and non toxic goitre) aspects. Patients with euthyroid goitre have no symptoms because there is no abnormality with the thyroid function. This study aimed to obtain the profile of the non toxic multinodosa goitre patients with euthyroidism in Surgery Department Prof. Dr. R. D. Kandou Hospital Manado period from July 2012 to July 2014. This was a descriptive retrospective study using the medical record of the Surgery Department Prof. Dr. R. D. Kandou Hospital Manado. Of 25 non toxic goitre multinodosa patients, there were 21 (84\%) female patient and 4 (16\%) male patient. Patients with euthyroidism were 21 cases (84\%) and with hypothyroidism 4 cases (16\%). Therapy of euthyroid goitre was surgery. The types of surgery for this 25 patient were as follows: 14 (56\%) total thyroidectomy, 9 (36\%) isthmolobectomy, 1 (4\%) nearly total thyroidectomy, and 1 case (4\%) subtotal thyroidectomy. Patients with enlargements in the neck should be checked for their thyroid glands and hormones even if they do not have any symptoms, especially if they come from iodine deficiency endemic area.
\end{abstract}

Keywords: goitre, euthyroid

\begin{abstract}
Abstrak: Struma adalah pembesaran kelenjar tiroid karena terjadi penambahan jaringan kelenjar tiroid. Struma dapat diklasifikasikan berdasarkan fisiologis (eutirodisme, hipotiroidisme, dan hipertiroidisme), morfologi (struma difus dan nodular) serta berdasarkan klinis (struma toksik dan non toksik). Penderita struma yang eutiroid tidak mempunyai keluhan karena tidak terdapat gangguan fungsi tiroid. Penelitian ini bertujuan untuk mengetahui gambaran pasien struma multinodusa non-toksik yag eutiroid di Bagian Bedah RSUP Prof. Dr. R. D. Kandou Manado periode Juli 2012 - Juli 2014. Penelitian ini bersifat deskriptif retrospektif dengan memanfaatkan catatan medik di Bagian Bedah RSUP Prof. Dr. R. D. Kandou Manado. Dari 25 pasien struma multinodusa non-toksik ditemukan bahwa jenis kelamin perempuan sebanyak 21 pasien (84\%) dan jenis kelamin laki-laki 4 pasien (16\%). Jumlah pasien yang eutiroid sebanyak 21 kasus (84\%) dan hipotiroid 4 kasus (16\%). Terapi struma eutiroid ialah pembedahan. Dari 25 kasus struma multinodusa non-toksik didapatkan 14 kasus (56\%) tiroidektomi total, 9 kasus (36\%) istmolobektomi, 1 kasus (4\%) tiroidektomi hampir total, dan 1 kasus (4\%) tiroidektomi subtotal. Pasien dengan pembesaran di daerah leher sebaiknya langsung dilakukan pemeriksaan kelenjar dan hormon tiroid walaupun tanpa gejala apapun, terutama yang berasal dari daerah endemis kekurangan yodium.
\end{abstract}

Kata kunci: struma, eutiroid 
Struma adalah setiap pembesaran kelenjar tiroid yang disebabkan oleh penambahan jaringan kelenjar tiroid. Struma dapat diklasifikasikan berdasarkan fisiologis, yaitu eutirodisme, hipotiroidisme, dan hipertiroidisme; berdasarkan morfologi yaitu struma difus dan struma nodular/ multinodular; serta berdasarkan klinis, yaitu struma toksik dan non toksik. ${ }^{1}$

Di seluruh dunia, penyebab paling umum dari struma ialah defisiensi yodium. Diperkirakan bahwa struma memengaruhi sebanyak 200 juta dari 800 juta orang yang kekurangan yodium. Angka kejadian struma baik difusa maupun nodosa sangat tergantung pada asupan yodium masyarakat. Pada area dengan defisiensi yodium, prevalensi struma dapat sangat tinggi. $^{2}$

WHO (1974) membuat kategori endemisitas suatu wilayah berdasarkan TGR dengan prevalensi struma sebagai indikator, yaitu TGR $<5 \%$ dikategorikan cukup yodium; TGR 5,0-19,9\% defisiensi yodium tingkat ringan; TGR 20,0-29,9\% defisiensi yodium tingkat sedang; dan $>30 \%$ defisiensi yodium tingkat berat. ${ }^{3}$

Eutiroid adalah keadaan dimana fungsi kelenjar tiroid dalam keadaan normal. Hipertiroid berarti kelenjar tiroid bekerja melebihi kerja normal sehingga biasanya kelenjar tiroid membesar dan juga akan didapatkan hasil laboratorium FT3 dan FT4 yang berada di atas normal, sedangkan TSH sering rendah. Hipotiroid kebalikan dari hipertiroid, dimana kelenjar tiroid bekerja di bawah normal, dalam hal ini FT4 di bawah angka normal., 1,2,4

Penderita struma nodusa yang eutiroid tidak mempunyai keluhan karena tidak terdapat gangguan pada hasil fungsi tiroid. Nodul dapat tunggal tetapi dapat berkembang menjadi multinodular tanpa perubahan fungsi. Degenerasi jaringan menyebabkan terbentuknya kista atau adenoma. Karena pertumbuhan terjadi secara perlahan, struma dapat menjadi besar tanpa menimbulkan gejala, selain adanya benjolan dileher. Sebagian besar penderita struma nodusa dapat hidup dengan struma tanpa keluhan. ${ }^{4}$

\section{METODE PENELITIAN}

Penelitian ini menggunakan metode deskriptif retrospektif dengan memanfaatkan data sekunder catatan medik Bagian Bedah RSUP Prof. Dr. R. D. Kandou Manado. Subjek penelitian ialah semua pasien dengan diagnosis struma multinodusa non-toksik di RSUP Prof. Dr. R. D. Kandou Manado selama periode Juli 2012 Juli 2014. Variabel penelitian ialah umur, jenis kelamin, interpretasi hasil pemeriksaan fungsi tiroid, dan jenis pembedahan.

\section{HASIL PENELITIAN}

Selama periode Juli 2012 - Juli 2014, didapatkan 30 kasus struma multinodusa non-toksik. Jumlah pasien perempuan lebih banyak daripada laki-laki (Tabel 1) dengan distribusi kasus terbanyak pada usia 36-45 tahun (Tabel 2).

Tabel 1. Distribusi berdasarkan jenis kelamin

\begin{tabular}{ccc}
\hline Jenis Kelamin & Jumlah & $\%$ \\
\hline Perempuan & 21 & 84 \\
Laki - Laki & 4 & 16 \\
Jumlah & 25 & 100 \\
\hline
\end{tabular}

Tabel 2. Distribusi berdasarkan kelompok umur

\begin{tabular}{ccc}
\hline Umur (tahun) & Jumlah & $\%$ \\
\hline Balita (0-5) & 0 & 0 \\
Anak (6-11) & 0 & 0 \\
Remaja Awal (12-15) & 0 & 0 \\
Remaja Akhir (16-25) & 2 & 8 \\
Dewasa Awal (26-35) & 7 & 28 \\
Dewasa Akhir (36-45) & 9 & 36 \\
Lansia Awal (46-55) & 3 & 12 \\
Lansia Akhir (56-65) & 3 & 12 \\
Manula (>65) & 1 & 4 \\
Jumlah & 25 & 100 \\
\hline
\end{tabular}

Tabel 3. Distribusi berdasarkan interpretasi hasil laboratorium

\begin{tabular}{ccc}
\hline Interpretasi & Jumlah & $\%$ \\
\hline Eutiroid & 21 & 84 \\
Hipotiroid & 4 & 16 \\
Jumlah & 25 & 100 \\
\hline
\end{tabular}


Tabel 4. Distribusi berdasarkan jenis pembedahan

\begin{tabular}{ccc}
\hline Jenis Pembedahan & Jumlah & $\%$ \\
\hline Tiroidektomi Total & 14 & 56 \\
Near Total Tiroidektomi & 1 & 4 \\
Isthmolobektomi & 9 & 36 \\
Tiroidektomi Subtotal & 1 & 4 \\
Jumlah & 25 & 100 \\
\hline
\end{tabular}

\section{BAHASAN}

Pada penelitian ini ditemukan sebanyak 25 kasus penderita struma multinodusa non-toksik sesuai dengan kriteria di Bagian Bedah BLU RSUP Prof. Dr. R. D. Kandou Manado Periode Juli 2012-Juli 2014.

Berdasarkan jenis kelamin didapatkan bahwa pasien yang menderita struma multinodusa non-toksik lebih banyak terjadi pada kelompok jenis kelamin perempuan yaitu sebanyak $84 \%$. Hasil ini memiliki kesamaan dengan penelitian yang dilakukan oleh Al-saig et al jumlah kasus struma multinodusa non-toksik sebanyak 60 kasus; 8 diantaranya laki-laki dan 52 pasien lainnya perempuan. ${ }^{5}$ Hasil ini sesuai dengan kepustakaan yang menyatakan bahwa prevalensi struma lebih sering terjadi di kalangan perempuan berhubungan adanya efek dari estrogen terhadap kelenjar tiroid. Estrogen dapat meningkatkan kadar thyroid binding globulin (TBG) yang bekerja sebagai transpor T4 dan T3 dalam darah sehingga terjadi penurunan kadar T4 bebas dan T3 bebas. Hal ini menstimulasi TSH sehingga terjadi hiperplasia kelenjar (struma) sebagai mekanisme kompensasi membentuk lebih banyak hormon tiroid agar kadar T4 dan T3 serum dapat kembali normal. Hal ini juga berlaku pada proses kehamilan dan pengguna kontrasepsi oral dimana terjadi peningkatan kadar TBG. Oleh karena itu perlu diperhatikan dalam menilai kadar T4 total dan T3 total pada pasien yang diperkirakan terjadi perubahan kadar TBG. ${ }^{6,7}$

Berdasarkan kelompok umur ditemukan bahwa kasus struma multinodusa nontoksik paling banyak terjadi pada kelompok umur dewasa akhir yaitu usia 36-45 tahun sebanyak 36\% dari 25 kasus yang diteliti, dan tidak ditemukan pada kelompok umur remaja awal, anak-anak, dan balita. Pada penelitian Azayati et al. di salah satu rumah sakit di Jakarta diperoleh data 10 orang pasien yang menunjukkan usia berkisar antar 25-62 tahun; tidak ditemukan pasien kelompok usia anak-anak. ${ }^{8}$

Struma dapat menyerang penderita pada segala umur namun umur yang semakin tua akan meningkatkan risiko penyakit lebih besar. Hal ini disebabkan karena daya tahan tubuh dan imunitas seseorang yang semakin menurun seiring dengan bertambahnya usia dan meningkatnya kebutuhan terhadap asupan yodium. Frekuensi struma meningkat seiring dengan usia dan subyek yang biasa diteliti hanya kelompok usia dewasa dan lansia tetapi dalam area endemik yang berat, struma dapat ditemukan pada kelompok praremaja. ${ }^{9}$

Berdasarkan interpretasi hasil pemeriksaan fungsi tiroid pada pasien struma multinodusa non-toksik sebagian besar menunjukan hasil normal (eutiroid) yaitu 21 dari 25 kasus (84\%) dan hipotiroid 4 dari 25 kasus (16\%). Pemeriksaan laboratorium fungsi tiroid dilakukan dengan menilai kadar TSH, T4, dan T3. TSH telah lama dianggap sebagai agen utama yang menentukan pertumbuhan tiroid dalam menanggapi setiap faktor yang menyebabkan perubahan kadar hormon tiroid. Jika terjadi penurunan kadar hormon tiroid (hipotiroid) maka akan terjadi sekresi TSH yng berlebihan. Hipersekresi TSH merangsang pertumbuhan tiroid dan meningkatkan biosintesis hormon T4 dan T3. Akibatnya terjadi peningkatan massa dan aktivitas fungsional dari kelenjar tiroid sehingga pasien mengalami pembesaran tiroid (struma) tapi secara metabolik tetap normal (eumetabolik/eutiroid). Konsep patogenesis struma non-toksik tersebut tidak sesuai dengan fakta yaitu kadar TSH normal pada sebagian besar pasien dengan struma non-toksik. Beberapa kemungkinan mekanisme yang dapat menjelaskan temuan yang berbeda ini yaitu: 1) defisiensi 
yodium menstimulasi TSH yang akan menyebabkan hiperplasia kelenjar tiroid. Oleh karena itu, faktor yang mempengaruhi kadar yodium dapat menyebabkan struma sebagai respon kompensasi; 2) telah terjadi peningkatan kadar TSH tetapi terlalu kecil untuk dideteksi dengan metode immunoassay atau peningkatan kadar TSH masih berada dalam batas normal. ${ }^{10}$

Sebuah penelitian yang dilakukan oleh Rahman menyatakan bahwa berdasarkan status hormonal dari total 50 pasien struma multinodular didapatkan 30 (76\%) pasien eutiroid, 8 (16\%) pasien hipertiroid, dan 4 (8\%) pasien hipotiroid. Sisanya didapatkan 4 (8\%) pasien dengan hipertiroid subklinis dan 4 (8\%) pasien dengan hipotiroid subklinis. ${ }^{11}$ Pada penilitian di Pakistan juga menunjukkan dari 142 pasien struma multinodusa didapatkan 112 pasien dengan hasil eutiroid baik secara klinis maupun secara biokimia. ${ }^{12}$

Berdasarkan jenis pembedahan ditemukan bahwa yang paling sering dilakukan pada penderita struma multinodusa non-toksik ialah tiroidektomi total sebanyak 14 dari 25 kasus (56\%). Tiroidektomi total adalah tindakan pengangkatan seluruh kelenjar tiroid. Hasil ini sesuai dengan ulasan Roewen $\mathrm{K}$ et al. yang membandingkan beberapa penelitian retrospektif dan menunjukkan bahwa total tiroidektomi meminimalisasikan tingkat kekambuhan dan operasi berulang terhadap pasien struma multinodusa. Banyak ahli bedah yang masih melakukan tiroidektomi subtotal namun tiroidektomi total merupakan pilihan terbaik secara keseluruhan. $^{13}$

Barczynski et al. meneliti total 600 pasien struma multinodusa non-toksik dan membandingkan hasil akhir pembedahan tiroidektomi total, prosedur Dunhill (total lobektomi unilateral ditambah kontralateral lobektomi subtotal), dan subtotal tiroidektomi bilateral, masing-masing 200 pasien dan mendapatkan bahwa selama masa follow-up 5 tahun persentase angka kejadian kekambuhan struma setelah tiroidektomi total $0,52 \%$, setelah operasi Dunhill 4,71\%, dan kekambuhan setelah subtotal tiroidektomi 11,58\%. Dari hasil tersebut tiroidektomi total dapat dianggap sebagai prosedur pilihan untuk pasien dengan struma multinodusa non-toksik terkait dengan insidens kekambuhan struma yang rendah. Namun, tiroidektomi total memiliki risiko pasca operasi yang lebih tinggi seperti hipoparatiroidisme dan paresis saraf laringeal. Hal ini perlu menjadi pertimbangan dalam menetukan jenis pembedahan yang tepat dan dalam penangananpasca operasi. ${ }^{14}$

\section{SIMPULAN}

Berdasarkan hasil penelitian di Bagian Bedah BLU RSUP Prof. Dr. R. D. Kandou Manado dapat disimpulkan bahwa kasus struma multinodusa non-toksik periode Juli 2012 - Juli 2014 lebih banyak terjadi pada kelompok jenis kelamin perempuan, kelompok umur dewasa akhir (36-45 tahun), dan jenis pembedahan yang paling sering ialah total tiroidektomi.

\section{SARAN}

1. Diperlukan pemahaman yang baik mengenai penyakit struma multinodusa non-toksik dan mekanisme kerja sistem hormon tiroid agar dapat membantu dalam diagnosis dan terapi.

2. Diperlukan edukasi yang baik mengenai penyakit struma yang sering disebabkan oleh kurangnya asupan yodium agar dapat mengurangi jumlah penderita.

3. Diperlukan manajemen sistem dokumentasi data pasien yang baik

\section{DAFTAR PUSTAKA}

1. Sander MA, Fina CS. Struma Multinodosa Non Toksika Intrathorakal (Laporahn kasus). Malang: Fakultas Kedokteran UMM

2. Nada A. Ahmed MA, Vilallonga $R$ Armengol M, Moustafa I, et al. A Giant Euthyroid Endemic Multinodular Goiter with No Obstructive or Compressive Symptoms. Gyza, Mesir. 2011. Case report in medicine. Volume 2011, Article ID 620480, doi:10.1155/2011/620480.

3. Djokomoeljanto R. Gangguan Akibat Kurang Yodium. In: Sudoyo AW, 
Setiyohadi B, Alwi I, Simadibrata MK, Setiati S, editors. Buku Ajar Ilmu Penyakit Dalam Jilid 3 (4th ed.). Jakarta: Pusat Penerbitan Departemen Ilmu Penyakit Dalam Fakultas Kedokteran Universitas Indonesia; p. 1946.

4. Utami IP. Asupan perawatan gangguan rasa nyaman (studi kasus). Surakarta: Sekolah Tinggi Ilmu Kesehatan Kusuma Husada, 2013.

5. Al-Saig TH, al-Omary MS, Zuhair M et al. Non toxic goiter: Cytology, Histological Analysis: a study in Mosul. Iraqi J. Comm. Med. 2011;24(4):325-30.

6. Sudoyo AW, Setiyohadi B, Alwi I, Simadibrata MK, Setiati S, editors. Buku Ajar Ilmu Penyakit Dalam Jilid 3 (4th ed.). Jakarta: Pusat Penerbitan Departemen Ilmu Penyakit Dalam Fakultas Kedokteran Universitas Indonesia; p. 1957.

7. Suherman S. Estrogen dan Progestin, Agonis dan Antagonisnya. In: Gunawan S, editor. Farmakologi dan Terapi (5th ed.). Jakarta: FKUI, 2007; p. 461.

8. Bahirah A, Milvita D, Nazir F. Analisis uptake tiroid menggunakan ROI
(Region of interest) pada pasien nodul tiroid. Jurnal fisika UNPAD. 2014;3(2):59-64.

9. Darmayanti N. Endemic goiter. Denpasar: Bagian Bedah Fakultas Kedokteran Udayana, 2012.

10.Larsen R. Williams Textbook of Endocrinology (10th ed.). Philadelphia: Elsevier, 2003.

11.Sadiq A, Mahmood S, Bashir E, Khan S. Corelation of thyroid function test and goitre. JRMF. 2012;16(2):153-5.

12.Rahman M. Biochemical status and cytopathological profile of patients presenting with multinodular goiter. J Medicine. 2011;12:26-9.

13.Rouwen K, Fest J. The best surgical approach for treating multinodular goiter (a systematic goiter). [Artikel Penelitian]. Eramus Jounal of Medicine. 2011;2(1):24-7.

\section{Barczynski M, Konturek A,} Huvbalewska-Dydejczyk A, Golkowski F, Cichon S, Nowak W. Five year follow up of a randomized clinical trial of total thyroidectomy versus Dunhill Operation versus Bilateral Subtotal Thyroidectomy for Multinodular Nontoxic Goiter. World J Surg. 2010;34(6):1203-13. 